\title{
HW-84556
}

ÁEC RESEARCH AND DEVELOPMENT REPORT

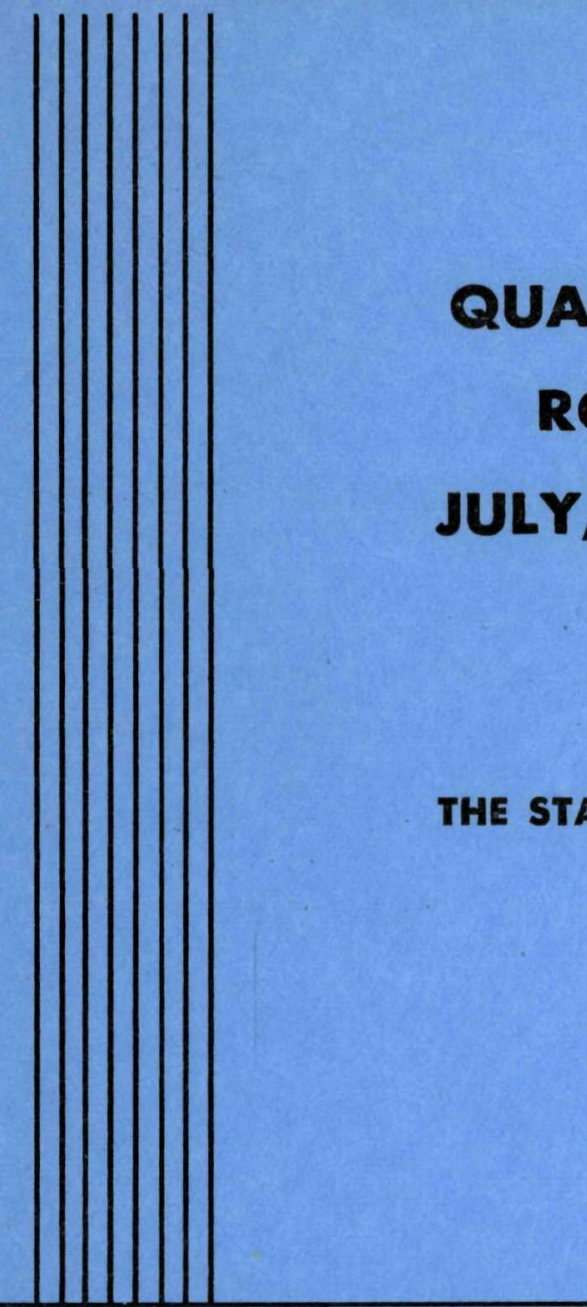

HANFORD LABORATORIES

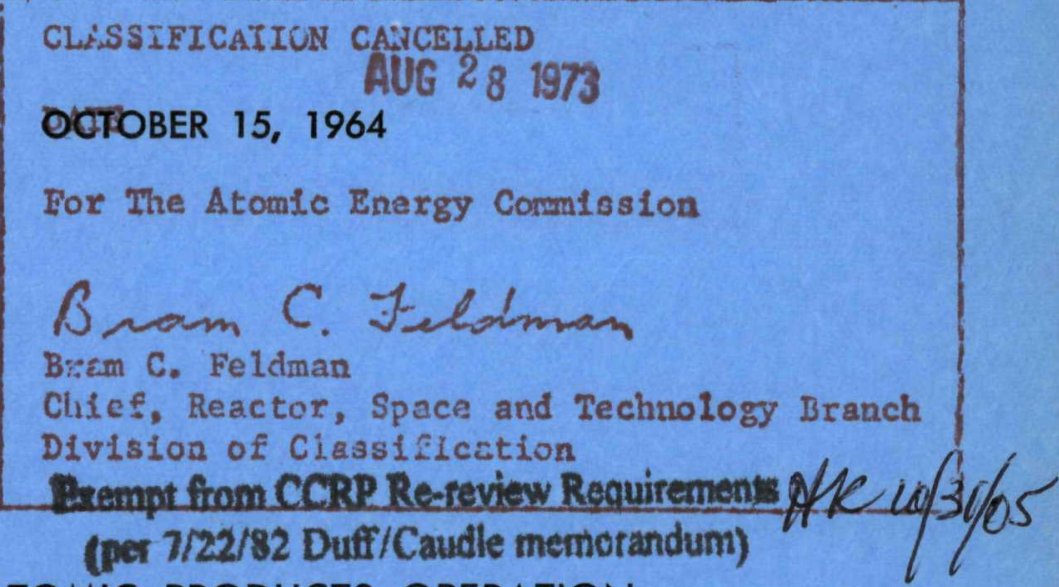

HANFORD ATOMIC PRODUCTS OPERATION

RICHLAND, WASHINGTON

\section{GENERAL GL6CTRIC}

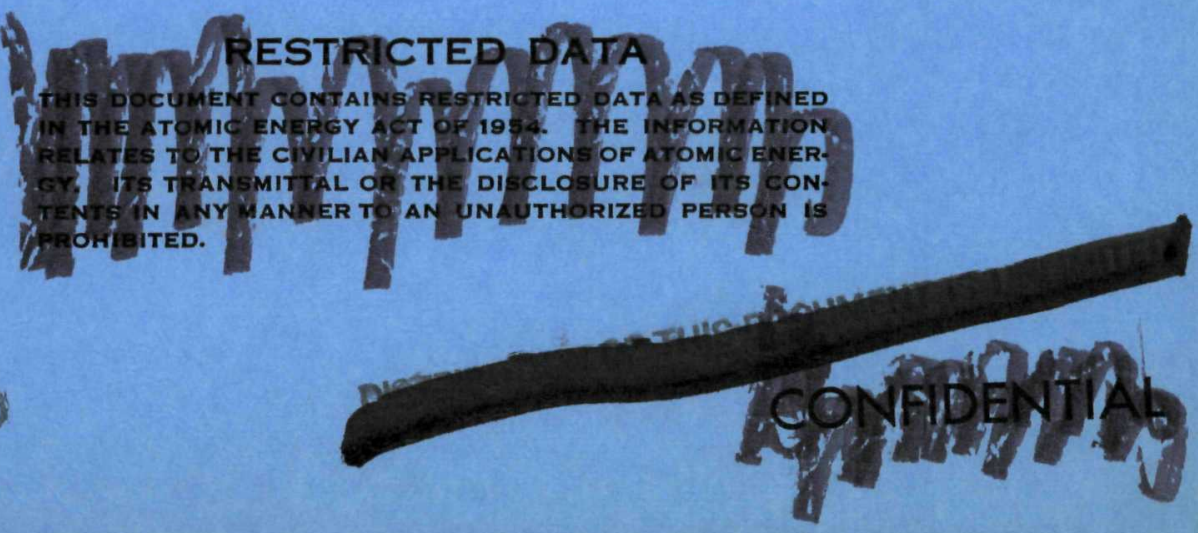




\section{DISCLAIMER}

This report was prepared as an account of work sponsored by an agency of the United States Government. Neither the United States Government nor any agency Thereof, nor any of their employees, makes any warranty, express or implied, or assumes any legal liability or responsibility for the accuracy, completeness, or usefulness of any information, apparatus, product, or process disclosed, or represents that its use would not infringe privately owned rights. Reference herein to any specific commercial product, process, or service by trade name, trademark, manufacturer, or otherwise does not necessarily constitute or imply its endorsement, recommendation, or favoring by the United States Government or any agency thereof. The views and opinions of authors expressed herein do not necessarily state or reflect those of the United States Government or any agency thereof. 


\section{DISCLAIMER}

Portions of this document may be illegible in electronic image products. Images are produced from the best available original document. 


\section{LEGAL NOTICE}

This report was prepared as an account of Government sponsored work. Neither the United States, nor the Commission, nor any person acting on behalf of the Commission:

A. Makes any warranty or representation, expressed or implied, with respect to the accuracy, completeness, or usefulness of the information contained in this report, or that the use of any information, apparatus, method, or process disclosed in this report may not infringe privately owned rights; or

B. Assumes any liabilities with respect to the use of, or for damages resulting from the use of any information, apparatus, method, or process disclosed in this report.

As used in the above, "person acting on behalf of the Commission" includes any employee or contractor of the Commission, or employee of such contractor, to the extent that such employee or contractor of the Commission, or employee of such contractor prepares, disseminates, or provides access to, any information pursuant to his employment or contract with the Commission, or his employment with such contractor. 


\section{UNCLASSIFIED}

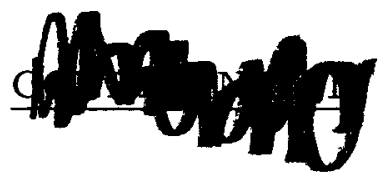

HW -84556

C-91, Nuclear Reactors

for Rocket Propulsion

(M-3679, 38th Ed.)

\section{QUARTERLY PROGRESS RE PORT \\ ROVER GRAPHITE STUDIES \\ JULY, AUGUST, SEPTEMBER, 1964}

By

The Staff of Reactor and Fuels Laboratory

October 15, 1964

HANFORD ATOMIC PRODUCTS OPERATION
RICHLAND, WASHINGTON

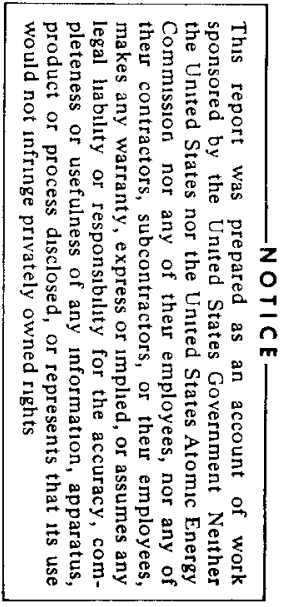

Work performed under Contract No. AT(45-1)-1350 between the Atomic Energy Commission and General Electric Company

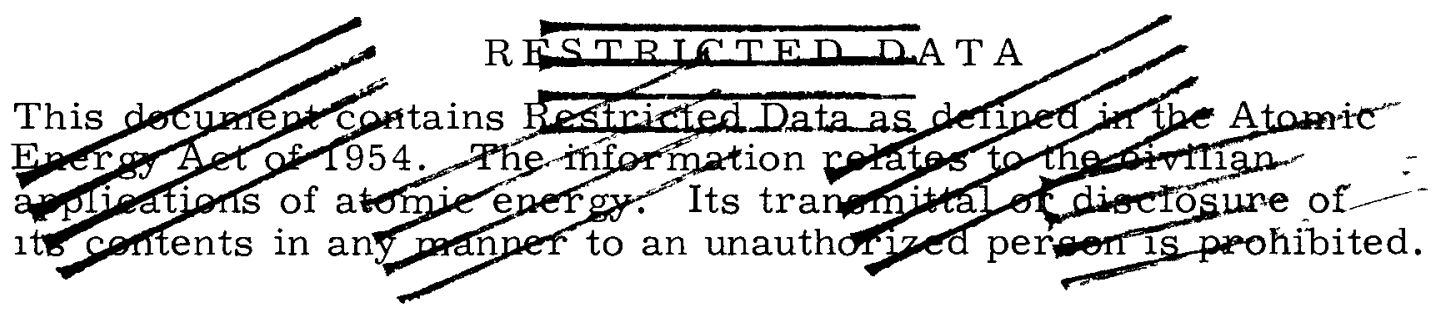

Printed in the USA. Charge \$0.35. Available from the U. S. Atomic Energy Commission, Division of Technical Information Extension, P. O. Box 1001, Oak Ridge, Tennessee. Please direct to the same address inquiries covering the procurement of other classified AEC reports.

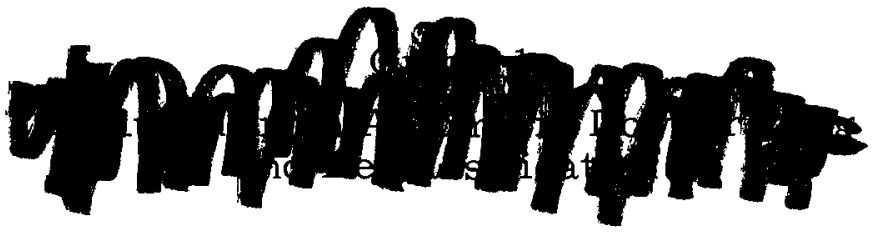

UNCI ACSIEIED

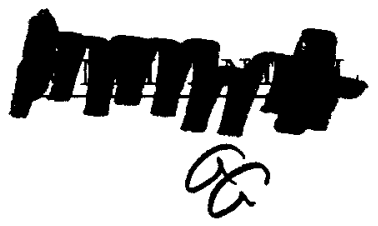




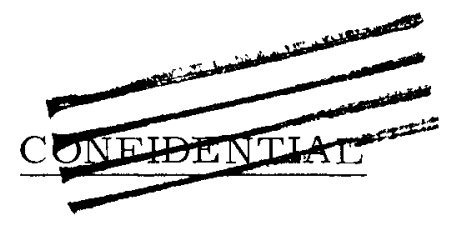

\author{
QUARTERLY PROGRESS REPORT \\ ROVER GRAPHITE STUDIES \\ JULY, AUGUST, SEPTEMBER, 1964
}

Migration Studies of Uranium Through Pyrolytic Carbon - C. E. McNeilly

The investigation of uranium migration through pyrolytic carbon coatings on uranium dicarbide particles has been continued using hot stage reflection electron miccroscopy. In order to overcome the problem of loss of image quality in the microscope due to evaporation of the graphite matrix, several specimens were prepared by pneumatically impacting a dispersion of coated particles in various refractory metal powders. The particles in the tungsten matrix cracked on impaction; however, those in the tantalum, niobium, and rhenium matrices appeared to be intact.

Because of the severe work hardening of rhenium during polishing, it has been impossible to obtain a satisfactory sample for examination. Time lapse motion pictures have, however, been obtained for tantalum and niobium matrix samples.

No reaction between $\mathrm{UC}_{2}$ and the PyC coating was observed in either case, although it was quite apparent that the PyC coating on the particles in the niobium matrix evaporated at a much faster rate than those in a tantalum matrix.

The most recent work has been directed towards a better understanding of the formation and adherence of the $\mathrm{NbC}$ coating used on the Rover graphite materials. Since coatings can be successfully applied to unfueled, but not fueled graphite, hot stage microscopy is being used to detect any difference in the two materials. Time lapse motion pictures of fueled and unfueled specimens containing a transparent niobium coating, have been taken and do show some differences. Similar pictures are being obtained on uncoated samples and comparisons between the four films will be made.

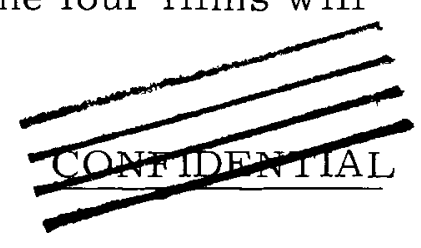




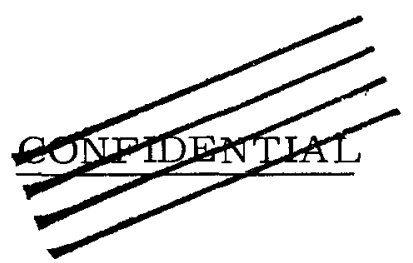

Niobium Carbide Coated Graphite Studies

$\underline{X-r a y}$ Investigation - L. D. Johnson

This X-ray investigation consisted of a crystallite orientation study of the fueled and unfueled graphites (Samples 45-2181 and 01-1685-105, respectively) and an examination of the diffraction patterns of the $\mathrm{NbC}$ coatings on the graphite.

The crystallite orientations were found by $X$-ray transmission using the Norelco type 52495 pole figure device. The average crystallite orientation, $\theta$, was calculated from the dependences of the (002) diffraction line intensity on sample position and orientation. The two transverse directions were assumed to have equal concentrations of $\underline{c}$ axes. The relative crystallite orientation is 0.22 and 0.28 , for the unfueled and fueled graphites, respectively. The unfueled sample was therefore significantly more anisotropic than the fueled graphite.

An attempt was made to determine the particle orientations in the $\mathrm{NbC}$ coatings by $\mathrm{X}$-ray reflection, but the rough surface texture and high $X$-ray absorption cross-section of the coatings made this analysis unfeasible.

\section{Reactor Rates - R. L. Gibby}

A study of the reaction between niobium and graphite has been initiated to determine why high quality niobium carbide coatings can be routinely applied to reactor grade graphite and not to graphite containing PyC coated $\mathrm{UC}_{2}$ fuel particles.

Experimental techniques are:

1. press fitting a small niobium pin into a graphite sleeve (fueled or unfueled) forming a diffusion couple

2. soaking the couple at an elevated temperature for a measured time

3. examining the reaction zone with $\mathrm{X}$-ray diffraction, metallography and microhardness measurements

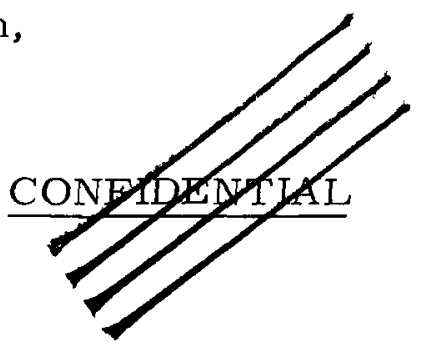


At present, four samples have been reacted at two different temperatures. Two samples were heated for $4 \mathrm{hr}$ at $1600 \mathrm{C}$, while two other samples were heated $4 \mathrm{hr}$ at $1900 \mathrm{C}$. In each case, one sample contained fueled graphite so that a comparison could be made between the reaction rates of niobium and fueled and unfueled graphite.

Reactions occurred in all four specimens but were more limited at the lower temperature. At the circumference of the niobium pins two distinct reaction products were observed (Figure 1). Microhardness measurements, with a Knoop indentor and a $50 \mathrm{~g}$ load, indicated that both phases had essentially the same hardness, with values between 1350 and 1780 . The niobium metal, on the other hand, tested under identical conditions, had a Knoop Hardness of 96. In some cases, reaction products were located at niobium grain boundaries (Figure 2). Knoop hardness measurements gave values of 1350 to 1780 for these reaction products.

At both temperatures there appeared to be no apparent difference in the reaction rates of niobium with fueled and unfueled graphite. Although the reaction products have not yet been identified, it is highly probable that they are $\mathrm{Nb}_{2} \mathrm{C}$ and $\mathrm{NbC}$, since these are the only reported carbides of niobium.

In continuing envestigations a polished flat diffusion couple is to be used in conjunction with inert boundary markers.

\section{UNCLASIFIED}

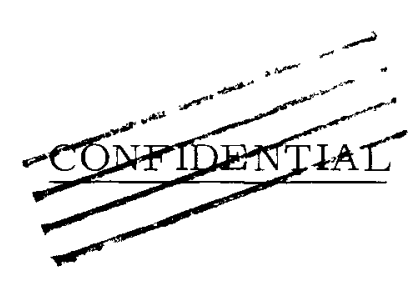




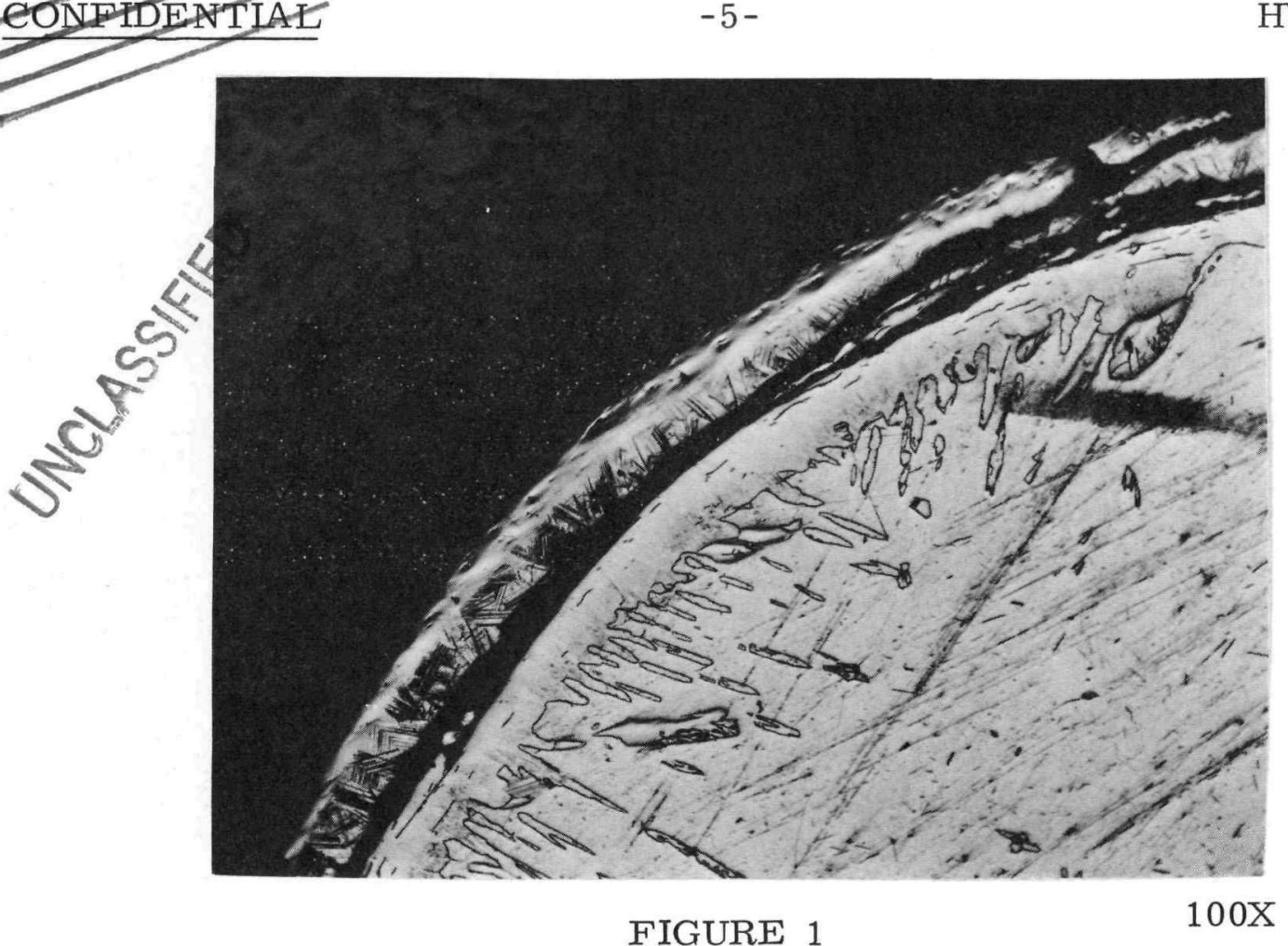

Reaction Zone at Circumference of Niobium Pin Heated $4 \mathrm{hr}$ at $1900 \mathrm{C}$

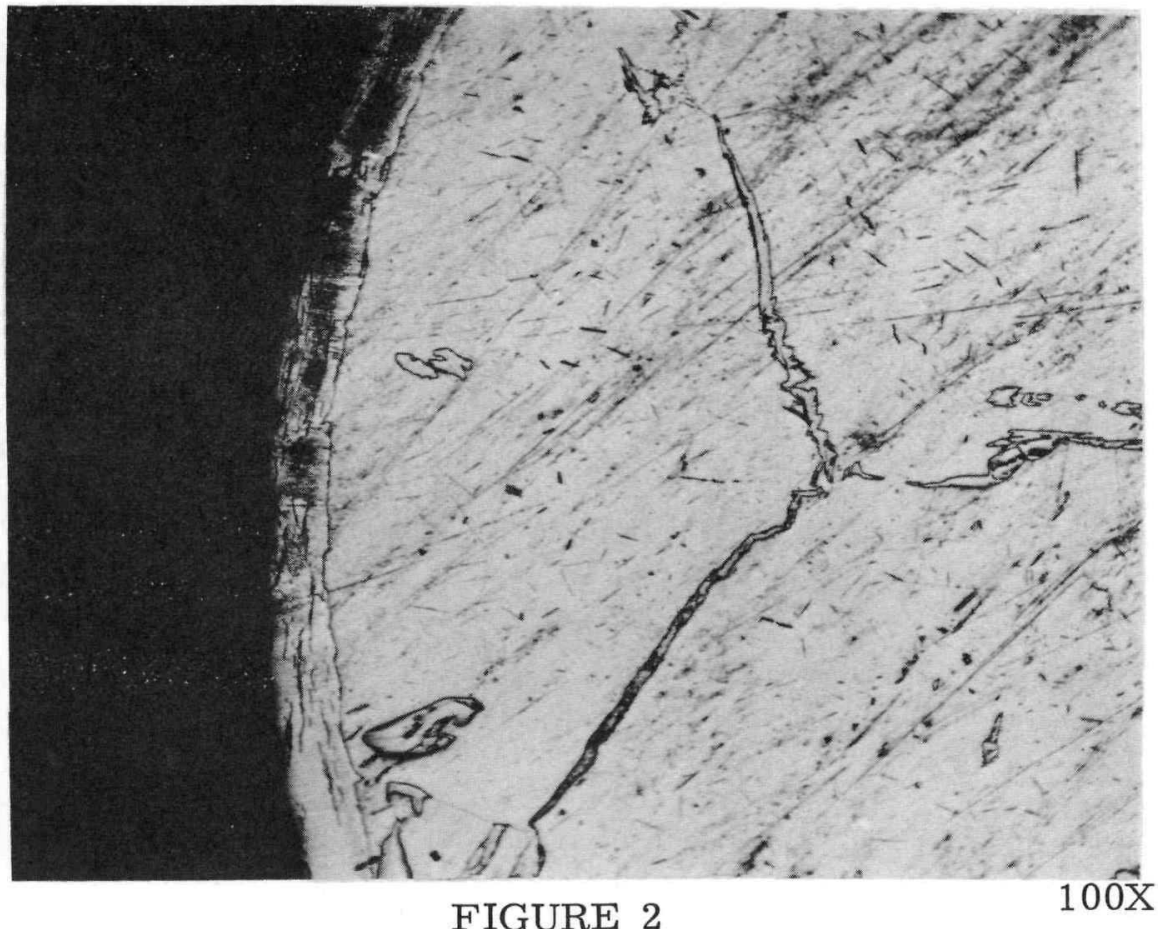

Reaction Products in Niobium

Neg. 441,442 Grain Boundaries After $4 \mathrm{hr}$ at $1900 \mathrm{C}$ 
Magnetic Force Welding of Graphite ${ }^{(1)}-$ C. H. Shaw

Feasibility studies on magnetic force welding of fueled to unfueled NASA Rover graphite elements have shown that at least partial bonding can be accomplished. Figure 3 is illustrative of the maximum bonding achieved to date.

Evaluation of most joints produced to date has been by metallographic techniques using the sensitive-tint photographic process on those joints of particular interest. Physical testing (tensile strength) of joints has been limited to only a few samples. The samples tested ranged in strength from 100 to 200 psi (based on total joint area), Metallographic examination of tensile samples after fracture, however, showed that the actual diffusion bond areas were quite small (less than $30 \%$ ) or nonexistent.

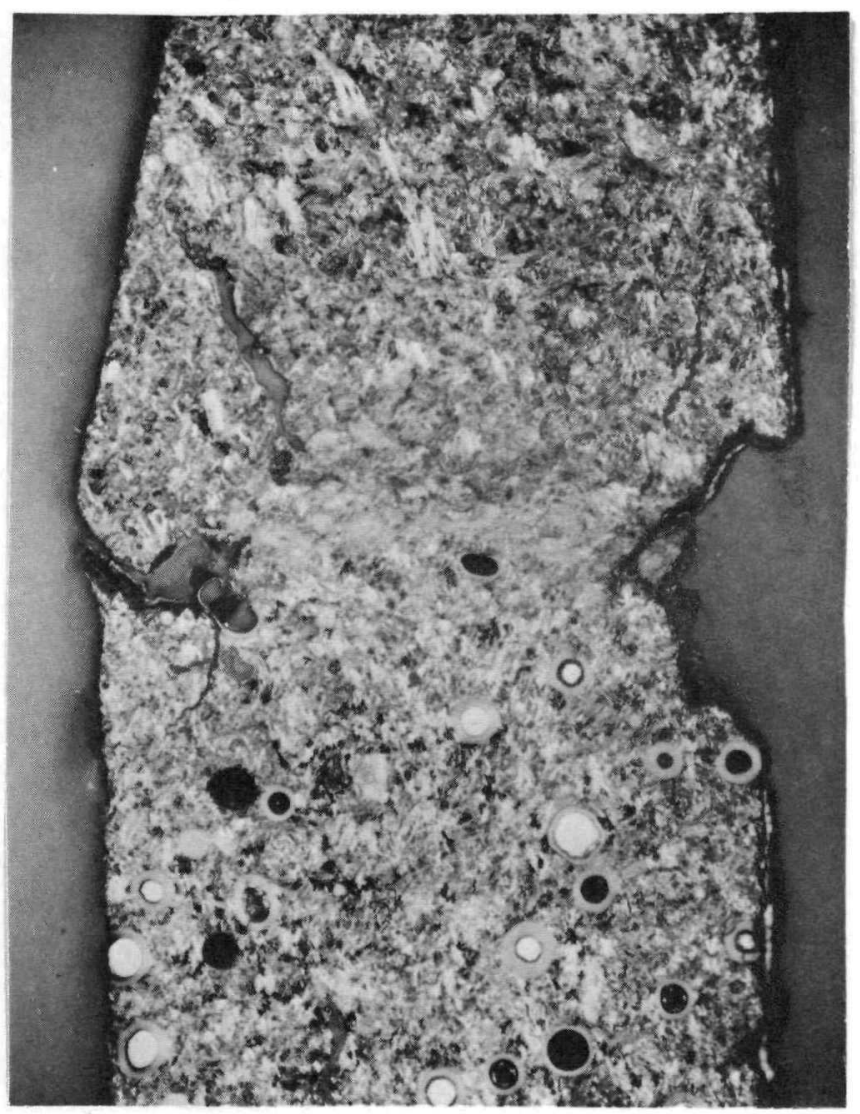

FIGURE 3

NASA Graphite Weld Test Sample

1. Progress Report: Fueled Graphite Studies, April, May, June, 1964, HW -83980 .

$$
\text { (Confidential) }
$$

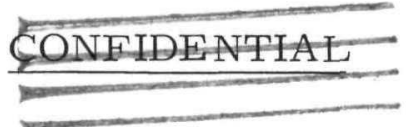




\section{INTERNAL DISTRIBUTION}

\section{Copy Number}

1 F. W. Albaugh

2 E. R. Astley

3 J. J. Cadwell

4 J. L. Daniel

5 D. R. de Halas

6 K. Drumheller

7 R. L. Gibby

8 H. Harty

9 L. D. Johnson

W. E. Roake

C. H. Shaw

O. J. Wick

E. M. Woodruff

H. H. Yoshikawa

300 File Copy

Record Center

Extra

Richland Operations Office Attn: P. G. Holsted

\section{EXTERNAL DISTRIBUTION}

$\begin{array}{ll}25 & \text { ACF Industries, Inc. } \\ 26-27 & \text { Aerojet-General Corporation (NASA) } \\ 28 & \text { Aerojet-General Corporation, Sacramento } \\ 29 & \text { Aerojet-General Nucleonics } \\ 30-31 & \text { Aeronautical Systems Division } \\ 32 & \text { Aerospace Corporation } \\ 33 & \text { Air Defense Command } \\ 34 & \text { Air Force Rocket Propulsion Laboratory } \\ 35 & \text { Air Force Surgeon General } \\ 36-37 & \text { Air Force Weapons Laboratory } \\ 38 & \text { Air University Library } \\ 39-40 & \text { Albuquerque Operations Office } \\ 41 & \text { Argonne National Laboratory } \\ 42 & \text { Army Ballistic Research Laboratories } \\ 43 & \text { Army Materials Research Agency } \\ 44 & \text { Army Missile Command } \\ 45 & \text { Army Nuclear Defense Laboratory } \\ 46 & \text { Aro, Inc. }\end{array}$


EXTERNAL DISTRIBUTION (contd)

\section{Copy Number}

47

48-57

58

59

60

61

62

63

64-65

66

67

68

69

70

71

72

73

74

75

76

77

78

79

80

81

82

83

84

$85-86$

$87-89$

90

91

92

93

94

$95-96$

97

$98-103$

104
AEC-NASA Space Nuclear Propulsion Office, Nevada

Atomic Energy Commission, Washington

Atomics International

Avco Corporation

Battelle Memorial Institute

Bendix Corporation (AF)

Braun (C. F.) and Company

Brookhaven National Laboratory

Bureau of Naval Weapons

Bureau of Naval Weapons (SPO)

Bureau of Ships

Central Intelligence Agency

Defense Atomic Support Agency, Sandia

Department of the Army

Director of Defense Research and Engineering (OSD)

du Pont Company, Aiken

Edgerton, Germeshausen and Grier, Inc., Goleta

Edgerton, Germeshausen and Grier, Inc., Las Vegas

Foreign Technology Division (AFSC)

General Atomic Division

General Dynamics/Fort Worth

General Electric Company, Cincinnati

General Electric Company (FPD)

Institute for Defense Analyses

Jet Propulsion Laboratory

Johns Hopkins University (APL)

Lockheed Missiles and Space Company

Lockheed Missiles and Space Company (NASA)

Los Alamos Scientific Laboratory

Los Alamos Scientific Laboratory

Attn: J. F. Cully

H. Hessing

D. P. McMillan

$\mathrm{M}$ and $\mathrm{C}$ Nuclear, Inc.

Marquardt Corporation

Martin-Marietta Corporation, Denver

Massachusetts Institute of Technology (Evans)

NASA Ames Research Center

NASA Goddard Space Flight Center

NASA Langley Research Center

NASA Lewis Research Center

NASA Manned Spacecraft Center 


\section{EXTERNAL DISTRIBUTION (contd)}

Copy Number

$105-108$

$109-111$

112

113

114

115

116

117

118

119

120

121

122

$123-124$

125

126-129

130

131

132

133

134

135

136

137

138

139

$140-144$

145

146

147

$148-149$

150

$151-152$

153-192

193
NASA Marshall Space Flight Center

NASA Scientific and Technical Information Facility

NASA Western Operations Office

Naval Missile Center

Naval Ordnance Test Station

Naval Postgraduate School

Naval Radiological Defense Laboratory

Nevada Operations Office

Nuclear Metals, Inc.

Nuclear Weapons Training Center Pacific

Oak Ridge Operations Office

Office of the Assistant General Counsel

for Patents (AEC)

Office of the Chief of Naval Operations

Office of the Chief of Naval Operations (OP-03EG)

Office of the Chief of Transportation

Phillips Petroleurn Company (NRTS)

Pratt and Whitney Aircraft Division

Pratt and Whitney Aircraft Division (NASA)

Rand Corporation

Rocketdyne

Sandia Corporation

School of Aerospace Medicine

Strategic Air Command

TRW Space Technology Laboratories

Union Carbide Corporation

Union Carbide Corporation, Lawrenceburg

Union Carbide Corporation (ORNL)

United Nuclear Corporation (NDA)

USAF Headquarters

USAF Headquarters (DCS/O)

University of California, Livermore

Westinghouse Electric Corporation (NASA)

White Sands Missile Range

Division of Technical Information Extension

Division of Technical Information Extension for retransmittal to:

AEC-NASA Space Nuclear Propulsion Office Washington, D. C.

Attn: J. F. Morrissey 